\section{Uranium mining's legacy}

\section{Munich}

THE costs to human health and the environment of 45 years of uranium mining in eastern Germany are becoming clear as a unified Germany contemplates cleaning up the radioactive mess left behind.

The recently terminated mining activities, which provided the Soviet Union with most of the uranium it needed for its early atomic bombs, have left behind a devastated wasteland close to heavily populated areas.

This otherwise dark cloud does, however, offer at least one small silver lining. It may provide researchers with one of the best opportunities since Hiroshima to learn about the effects of radiation on humans.

Making the uranium mining areas once again safe for human habitation will probably be the costliest clean-up in German history. The expense has been estimated at between DM 5,000 million and DM 15,000 million $(\$ 2,800$ million $\$ 8,300$ million), although officials of the Environment Ministry say privately that it may ultimately cost much more than that.

The human costs have been equally severe. According to official figures, at least 5,200 miners died from "Schneeberg lung disease", a form of lung carcinoma named after one of the uranium mining towns, which are found in the Erzgebirge mountains in Saxony and Thuringia along the southern rim of what used to be East Germany.

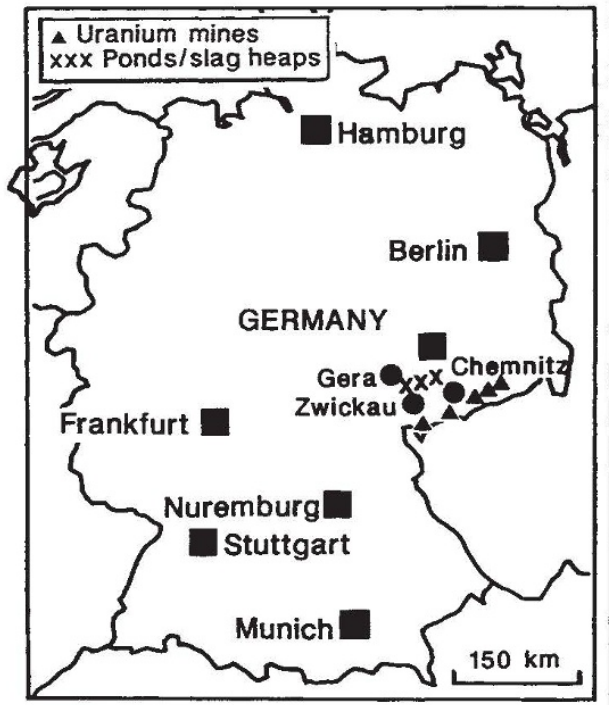

But no one knows if this figure is accurate, and some researchers think many more people have died. Munich physicist Eckhard Krüger, who visited the region recently, estimated last month that there could have been as many as 15,000 radiation deaths among the miners and the local population, but he admits that this is just a guess.

The German Environment Ministry is now looking into the matter. Recently, the ministry launched a preliminary investigation to determine the health effects of radiation on mine workers, who are thought to have been endangered most. The study is expected to be completed by the end of August.

Making an accurate assessment of the health effects on mine workers - for epidemiologists the most interesting group will turn on the answers to a few critical questions. How accurately can officials now estimate the radiation dose received by the individual miners? To what extent can medi$\mathrm{cal}$ records from the region be trusted? And to what extent can the natural background radiation in the region be determined? For the crucial period between 1946 and 1955 , when miners were provided with almost no protection from radiation by the Soviet owners of the mines, there are virtually no individual dose data, says Hans-Henning Landfermann, a radiation protection official of the Environment Ministry in Bonn. Nevertheless, researchers hope that, by using data on overall radiation levels in the areas where the miners were working, at least the gross effects can be measured.

The medical records from the region are also the object of some controversy. Doctors working under the Communist government were expected to file reports that were not alarming, says Edmund Lengfelder, a radiation biologist at the University of Munich, and therefore the reports did not accurately reflect the true health of the population.

Landfermann disagrees about the extent to which records were falsified. At least for the miners, he says, company doctors at Wismut AG, the jointly owned Soviet-East German company that operated the mines and was taken over last year by the German Economics Ministry, were willing to recognize lung cancer as a work-related illness.

Determining the natural background radiation in the region presents still other problems. Because the region where the mines are found was also mined heavily for silver, nickel and other metals, uranium ores have been dug up and discarded at least since the fifteenth century, says Dietmar Weiss of the Environment Ministry's regional office in Berlin. So the background levels of radiation could have been high even before 1945 .

Other influences may have as much to do with the health problems of the people in the region as radiation doses. Ministry officials found that tonnes of arsenic and heavy metals had been unearthed because of both silver and uranium mining. Furthermore, in the early years, when as many as 500,000 miners lived and worked in the region, they were treated to fringe benefits such as extra cigarettes that may well have contributed to a rapid decline in their health.

The government recently admitted in effect that the effects of the mining were more severe than previously thought when it began to compile a new registry of waste dumps and other sites affected by mining operations.
NEWS IN BRIEF

\section{Call for brain-maps}

AN Institute of Medicine report, published in Washington last week, calls for $\$ 10$ million a year to be set aside over five years to begin developing three-dimensional computerized maps of the human brain, as well as of the brains of key laboratory animal species. The initial request is small, requiring an addition of less than one per cent to the annual US neurosciences budget. But the entire project, conceived as a 20 -year initiative, is the most ambitious biological informatics programme proposed to date. The construction of databases to hold human gene mapping and sequence data, now underway under the auspices of the Human Genome Project, is a minor problem in comparison.

As envisaged in the report, brain researchers will be able to explore threedimensional computer maps of the brain, focusing on a particular area and calling up a wide range of information from linked databases about the region in question including function, pharmacology, and connections to other brain areas. P.A.

\section{Californian quake}

THE largest magnitude earthquake to hit California since the Loma Prieta event of 1989 left two dead last Friday (28 June). The 5.8 magnitude quake, centred $11 \mathrm{~km}$ beneath the San Gabriel mountains north of Pasadena, is the first with a magnitude greater than 4.5 to be recorded on that region of the Sierra Madre fault since seismologists began monitoring in the 1920s. Lucy Jones, from the US Geological Survey at Pasadena, says there had been some debate as to whether the fault was dead. "Obviously it's not." Jones adds that the latest quake is the fourth around the San Gabriel mountains since 1987. The combined effect of these events is to rotate the San Gabriel valley in a clockwise direction, she says.

P.A.

\section{Eastern European aid}

THE UK government has added $£ 5$ million to its aid for Eastern Europe to start a new exchange programme for environmental researchers. As part of the existing $£ 30 \mathrm{mil}-$ lion "Know How" economic aid programme, the three-year exchange effort will bring Eastern European researchers to Britain to learn environmental restoration techniques, and send UK researchers to Eastern Europe to work alongside scientists there. In announcing the new programme, UK environment secretary Michael Heseltine said he had learned "not always willingly" - the importance of non-governmental organizations like Greenpeace in raising public consciousness towards environmental problems. One of the Know How projects will bring leaders of Czech and Slovak non-governmental organizations to Britain next month to work with their counterparts.C.A. 